\title{
Correction to: Changing Patterns of Commercial Sex Work Amongst Adolescent Girls in Nepal: The Role of Technology
}

\author{
Anita Ghimire $^{1}$ D $\cdot$ Fiona Samuels $^{2} \cdot$ Sarmila Mainali $^{1}$
}

Published online: 4 October 2021

(c) The Author(s) 2021

\section{Correction to: The European Journal of Development Research https://doi.org/10.1057/s41287-021-00455-4}

The article 'Changing Patterns of Commercial Sex Work Amongst Adolescent Girls in Nepal: The Role of Technology', written by Anita Ghimire, Fiona Samuels and Sarmila Mainali, was originally published electronically on the publisher's internet portal on 30 of August 2021 without open access. With the author(s)' decision to opt for Open Choice the copyright of the article changed on 16 of September 2021 to (C) The Author(s), 2021 and the article is forthwith distributed under a Creative Commons Attribution 4.0 International License, which permits use, sharing, adaptation, distribution and reproduction in any medium or format, as long as you give appropriate credit to the original author(s) and the source, provide a link to the Creative Commons licence, and indicate if changes were made. The images or other third party material in this article are included in the article's Creative Commons licence, unless indicated otherwise in a credit line to the material. If material is not included in the article's Creative Commons licence and your intended use is not permitted by statutory regulation or exceeds the permitted use, you will need to obtain permission directly from the copyright holder. To view a copy of this licence, visit http://creat ivecommons.org/licenses/by/4.0.

The original article has been corrected.

Open Access This article is licensed under a Creative Commons Attribution 4.0 International License, which permits use, sharing, adaptation, distribution and reproduction in any medium or format, as long as you give appropriate credit to the original author(s) and the source, provide a link to the Creative Commons licence, and indicate if changes were made. The images or other third party material in this

The original article can be found online at https://doi.org/10.1057/s41287-021-00455-4.

Anita Ghimire

bhattarainitu@gmail.com

1 Nepal Institute for Social and Environmental Research, Lalitpur, Nepal

2 Overseas Development Institute, London, UK 
article are included in the article's Creative Commons licence, unless indicated otherwise in a credit line to the material. If material is not included in the article's Creative Commons licence and your intended use is not permitted by statutory regulation or exceeds the permitted use, you will need to obtain permission directly from the copyright holder. To view a copy of this licence, visit http://creativecommons.org/ licenses/by/4.0/.

Publisher's Note Springer Nature remains neutral with regard to jurisdictional claims in published maps and institutional affiliations. 